IZA DP No. 8179

\title{
Payment for Ecosystem Services from Forests
}

Jennifer Alix-Garcia

Hendrik Wolff

May 2014 


\title{
Payment for Ecosystem Services from Forests
}

\author{
Jennifer Alix-Garcia \\ University of Wisconsin \\ Hendrik Wolff \\ University of Washington \\ and IZA
}
Discussion Paper No. 8179
May 2014

IZA
P.O. Box 7240
53072 Bonn
Germany

Phone: +49-228-3894-0

Fax: +49-228-3894-180

E-mail: iza@iza.org

Any opinions expressed here are those of the author(s) and not those of IZA. Research published in this series may include views on policy, but the institute itself takes no institutional policy positions. The IZA research network is committed to the IZA Guiding Principles of Research Integrity.

The Institute for the Study of Labor (IZA) in Bonn is a local and virtual international research center and a place of communication between science, politics and business. IZA is an independent nonprofit organization supported by Deutsche Post Foundation. The center is associated with the University of Bonn and offers a stimulating research environment through its international network, workshops and conferences, data service, project support, research visits and doctoral program. IZA engages in (i) original and internationally competitive research in all fields of labor economics, (ii) development of policy concepts, and (iii) dissemination of research results and concepts to the interested public.

IZA Discussion Papers often represent preliminary work and are circulated to encourage discussion. Citation of such a paper should account for its provisional character. A revised version may be available directly from the author. 


\section{ABSTRACT}

\section{Payment for Ecosystem Services from Forests}

Every year between 2000 and 2010, our planet lost native forests roughly the size of Costa Rica. (FAO, 2010). This rapid deforestation has dramatically changed the chemical composition of the world's atmosphere, the level of biodiversity, and the presence of vegetation key to maintaining watershed function and preventing landslides. There has been a boom in the design of local and international policy instruments to prevent further deforestation and encourage forest growth. This paper reviews the theory and evidence surrounding forest-related Payment for Ecosystem Services (PES) schemes intended to slow and reverse deforestation. We cover the most recent work touching on a range of issues related to PES programs, including research on targeting, contract design, environmental effectiveness, challenges to program implementation, spillovers, and distributional considerations of conditional cash transfers. We also highlight areas of potential future research.

JEL Classification: H23, H43, J43, Q23

Keywords: environmental policy, deforestation, afforestation, reforestation, climate change, conditional cash transfers, PES

Corresponding author:

Hendrik Wolff

University of Washington

Department of Economics

349 Savery Hall, Box 353330

Seattle, WA 98195-3330

USA

E-mail: hgwolff@u.washington.edu

\footnotetext{
${ }^{*}$ We would like to thank Austin Gross for excellent research assistance. Special thanks are due to Gardner Brown and one anonymous referee. Further, Shirley Park of the Annual Review has been very helpful throughout in supporting our work. Hendrik Wolff acknowledges financial support from the National Science Foundation, Grant No. 1156271.
} 


\section{Introduction}

During the first decade of this century, global net forest loss totaled over 5 million hectares per year, with 13 million hectares being completely destroyed on a yearly basis (FAO, 2010). This corresponds to the disappearance of 1.5 soccer fields of forest every two seconds, or the equivalent of the area of Costa Rica annually. It has recently been estimated that the total contribution of deforestation and forest degradation to anthropogenic CO2 is approximately $12 \%$, making it the second most important carbon source behind fossil fuels (Friedlingstein et al.., 2010). In addition to carbon, forests also provide many important local environmental goods such as erosion control and the maintenance of watershed functions. Furthermore, forest in the tropics also houses tremendous biodiversity - a warehouse of potential future benefits to society as a whole.

Partially driven by estimates in the Stern Report (2006), the global perception has been that reducing emissions from deforestation or providing additional sinks through the regeneration and expansion of forest would be inexpensive (\$1-2 per ton of CO2) relative to other approaches to climate change mitigation. This perceived low cost is the result of the global distribution of forests and deforestation, which is shown in Figure 1. The left vertical axis measures forest areas as of 1990 by world region and the right subsequent rates of forest loss from 1990. The figure reveals that Europe and South America contain the largest areas of forest resources, while Central American houses the highest rate of forest loss, followed by Africa and South America. In comparison, forest resources in North America, Europe and Asia appear to be at little risk. The possibility of potential low cost carbon sequestration in developing countries accelerated the development of various afforestation, deforestation, and reforestation programs, including the growing movement of payments conditional on forest conservation that had been developing in 
Latin America. In 1997, Costa Rica developed one of the first national-level forest Payment for Ecosystem Services (forest-PES) programs explicitly intended to pay for avoided deforestation. Other national-level programs quickly followed ${ }^{1}$. Throughout the late 1990s and early 2000s, a large number of city and regional level PES programs were initiated. By 2002, Landell-Mills and Porras documented more than 300 payment incentive programs worldwide.

\section{INSERT FIGURE 1 HERE}

That class of forest-PES programs is the topic of this review. In particular, we intend to examine the recent theoretical and empirical literature on forest-PES, and highlight areas where further research is necessary. Specifically, we will examine work on programs that award transfers conditional on either afforestation (expansion of forest), reforestation (replanting of forest), or avoided deforestation (prevention of forest loss). China's Sloping Land Conservation Program (Uchida, Xu, \& Rozelle, 2005) provides one of the best known cases of afforestation program, the Greening India Program (Balooni \& Singh, 2001) of reforestation, and Costa Rica's Programa de Pagos por Servicios Ambientales (Arriagada, Ferraro, \& Sills, 2012) of avoided deforestation.

There have already been several excellent reviews of payments for forest ecosystem services, including Pattanayak, Wunder, and Ferraro's (2010) review of the environmental effectiveness of avoided deforestation payments, and the PES section of Pfaff, Amacher, and Sills (2013), which examines how PES might address underlying drivers of deforestation. There have also been extensive overviews of the relationship between PES and poverty alleviation (see Bulte et al. (2008) and, more recently, parts of Samii et al. (2013), among others). Our purpose

\footnotetext{
${ }^{1}$ Historically, the earliest versions of PES payment schemes have been in existence since at least the 1980s, where payments to upstream farmers were designed to preserve water quality in Munich and New York City (Grolleau and McCann, 2012).
} 
here is not to repeat the discussions of these papers. Instead, we make an effort to focus on the latest developments, citing mostly papers that appeared recently—roughly between 2005 to mid of 2013 - although historical context is often provided by older work as well. This article is meant to provide a complement to the existing reviews and hence should be of interest for the reader who aims to update herself on the current status of the literature. Furthermore, we hope to broaden the perspective by examining afforestation and reforestation PES efforts in addition to avoided deforestation efforts.

Because at its core, a forest-PES contract is a Coasian market mechanism to internalize the negative externalities associated with forest loss, and to subsidize positive externalities associated with forest expansion, we begin our review in Section 2 by considering the nature of demand for forest services. On the demand side, this section discusses how the identity of the PES consumer dictates the scale of a PES program. Examples range from single-city watershed services to global transfers addressing climate change. Section 3 examines the supply side. Issues related to the identity of the PES seller, targeting, pricing, and the extent to which PES programs generate environmental services are reviewed. Section 4 describes additional challenges to implementation that are important for the scaling up to a national or global level: the common problem of insecure land tenure in many developing countries, and the possibility of program leakage. Section 5 considers potential social spillover effects of PES programs, with much of the space dedicated to the work discussing whether PES can serve to alleviate poverty, and if it affects other household or community behaviors. Finally, our conclusion highlights areas for further research. 


\section{Demand: Who buys forest ecosystem services?}

This section presents a variety of examples of environmental service buyers. ${ }^{2}$ On a spatial level forest-PES projects can be categorized into three groups: local, regional and global. For example, landslides resulting from localized deforestation represent a very distinct environmental service from carbon emissions, where the location of the forest has almost no impact on its contribution to the global $\mathrm{CO}_{2}$ service. In principle, going from local to global, the transaction costs of organizing and implementing the PES scheme increases considerably, as the examples in the following subsections will demonstrate. Interestingly, projects of all spatial scales have both private and public sector buyers with specific interests in the goods produced.

\section{Local public goods}

Local public goods associated with forest preservation and expansion include hydrological services and erosion prevention, among others. These types of programs are now relatively common in Latin America, where they have often been spearheaded by cities concerned with their water supply (Arriagada et al.., 2012; Van Hecken, Bastiaensen, \& Vásquez, 2012; Wunder \& Albán, 2008). In Ecuador, for example, the municipality of Pimampiro targeted 27 households holding land in the watershed that provides the city's water, eventually contracting with nineteen to halt their agricultural expansion into the forest and alpine grassland (Wunder \& Albán, 2008). Similar arrangements have been developed in Coatepec, Mexico, where efforts to address water security led to Mexico’s first hydrological services PES (Scullion et al., 2011).

An excellent example of a private buyer is the water bottling company Vittel, whichnegotiated agreements with the farmers in the catchment area feeding the company's

\footnotetext{
${ }^{2}$ This overview does not by any means constitute an inventory of PES schemes (which can be found in Landell-Mills and Porras (2002) and Pattanayak et al. (2010)), but rather hopes to emphasize how the nature of the externality affects the scale of its purchase.
} 
spring source (Wunder \& Wertz-Kanounnikoff, 2009). The current Vittel scheme, which has been in place for over ten years, consists of one buyer and 26 sellers of ecosystem services, and covers an area of about 3,500 ha. Further examples from Costa Rica involve hydropower producers, water bottlers, and tourism (Pagiola, 2008). These local agreements embody the Coasean ideal of private consumers dealing directly with suppliers to arrive at mutually agreeable terms, though in many cases, such as Costa Rica, intermediary NGOs play an important role in brokering deals.

\section{Regional or national public goods}

Because of the large number of land owners involved, regional agreements are usually driven by public buyers at the state or national level. Common examples of regional public goods include hydrological services, as well as erosion control. A prime example of this type of policy is China’s Grain for Green program, which has the goal of preserving and improving water as well as soil quality for entire river basins through set-asides of sloped land for re- and afforestation. Uchida et al.. (2005) summarize that between 1999 and 2001, participating farmers converted nearly 1.2 million hectares of cropland into forest and pasture and afforested nearly 1 million hectares of land. The program goal is to have set aside nearly 15 million hectares of cropland by 2010, an area almost equivalent to the US Conservation Reserve Program (Uchida et al., 2005). Further examples are Costa Rica's PSA, where the national government purchases avoided deforestation for regional hydrological services (Pagiola, 2008) and Mexico's Payments for Hydrological Services program.

Two interesting cases of private regional buyers are Ecuador's PROFAFOR and Panama's ForestRe. PROFAFOR is an extension of the Forests Absorbing Carbon-dioxide Emissions Consortium (which is in turn financed by Dutch energy companies) and signs 
contracts for afforestation and reforestation, accounting for 'almost half of all Ecuadorian reforestation’ since its inception in 1993 (Wunder \& Albán, 2008). ForestRe, on the other hand, is a reinsurance firm that established a watershed protection plan along the Panama Canal to reduce outlays on dredging and upkeep of the canal (Ecosystem Markets Task Force, 2012). The firm established a twenty-five year bond (funded by shippers and insurance firms) to restore forest ecosystems. ${ }^{3}$

\section{Global public goods}

Carbon sequestration and biodiversity are the two most prominent examples of public goods whose benefits transcend national boundaries. Today, both public and private buyers are very active in this market. Public buyers include national governments as well as multilateral purchases organized through international agreements by the United Nations and the World Bank. In fact, without considerable internal political support, it remains difficult for a single government to justify individual action on global public goods. In one of the few examples of a single-country driven PES for global public goods, Mexico in 2004 designed the Payments for Carbon, Biodiversity and Agro-forestry (PSA-CABSA) program. The program was later combined with the much larger Payments for Hydrological Services program, whose funding is predicated on providing public goods whose main beneficiaries are within the territorial boundaries of Mexico (Corbera, Soberanis, \& Brown, 2009).

There are a variety of global agreements whose intention is to overcome the cooperation dilemma. A longstanding example of this is the Clean Development Mechanism (CDM). Agreed upon in the United Nations Framework Convention on Climate Change (UNFCCC) and implemented by the Kyoto Protocol in 1997, the CDM allows firms to purchase Certified

\footnotetext{
${ }^{3}$ http://www.forestre.com/
} 
Emissions Reductions (CER) from offsets brought about in developing countries. The main purchaser of CER has been the EU Emissions Trading System, which uses these CER as part of the approved offsets for member states (Newell, Pizer, \& Raimi, 2013). Currently the CDM projects can involve afforestation and reforestation projects only. CDMs cannot cover avoided deforestation projects. Worldwide Thomas, Dargusch, Harrison, \& Herboh (2010) note that CDM forest projects account for less than $1 \%$ of the total of 8866 CDM projects, but could potentially expand in the near future if further cap-and trade systems will be implemented.

The second global mechanism of increasing importance is the UNFCCC initiative Reduced Emissions from Deforestation and Forest Degradation (REDD). REDD is a large scale forest-PES program, with funds being transferred from developed to developing countries. In comparison to the above forest-CDM projects which focus on afforestation and reforestation, REDD focuses, as the name suggests, on deforestation and forest degradation projects. Initially, REDD started as an effort to design incentives to create value for stored forest carbon. Though its roots can be found in much earlier climate negotiations, the mechanism was first formalized in the $200511^{\text {th }}$ Conference of the Parties (COP) in Montreal. The 2007 negotiations in Bali added reforestation and forest enhancement to the list of potential REDD strategies and rechristened the agreement REDD+. REDD+ also broadens the agreement to allow for the simultaneous consideration of other environmental goals (i.e. biodiversity, sustainable forest management), as well as other socio-economic aspects (i.e. indigenous rights and equity in distribution of funds and financing mechanisms). ${ }^{4}$ Multiple international organizations have

\footnotetext{
${ }^{4}$ According to the United Nations program, the main differences between REDD and REDD+ involve the following four aspects:

1) Equal priority between reducing emissions through Deforestation and Degradation, and removals through sinks such as conservation, sustainable management of forests and enhancement of forest carbon stocks.
} 
stepped in to facilitate the development and financing of REDD+ programs, including the World Bank’s Forest Carbon Partnership Facility (FCPF), which accepts both public and private funds, and UN-REDD.

National and local forest PES programs, however, are just one of a variety of strategies that countries might use to achieve REDD+ goals. Currently, most REDD+ programs are still in the development stage. To date, UN-REDD has financed the development of REDD+ strategies in 16 partner countries, and the World Bank's FCPF in 36 countries. While the economics literature is still scarce on evaluating these REDD projects, below we point towards various recent papers, highlighting different examples of private, public and NGO based REDD-type initiatives.

Some of the best examples of up-and-running REDD projects have been created in the private sector and by NGOs: Asner et al. (2010) describes the Madre de Dios Amazon REDD project, created by the NGO Greenoxx ${ }^{5}$. Covering 100,000 hectares of the Peruvian Amazon, it is expected to generate 9.5 million carbon credits over a ten year period. The first tons of CO2 traded by the project occurred in May 2010. A second privately financed REDD project is run by Marriott International who pledged 2 million USD towards the REDD project of the Juma Reserve in Brazil (Champagne \& Roberts, 2009). Other interest from the private sector has come from airlines, which offer carbon offsets for purchase by individuals wishing to offset carbon emissions generated by their air travel (Sarkar et al., 2008).

2) Long-term estimations of emission and removals should be done on a land basis instead of an activity basis since land-based approaches reflect more accurately the land's true effect on the environment and it is more consistent with the principle of environmental integrity.

3) Inclusion of the rights of Indigenous Peoples and new social and environmental safeguards.

4) Introduction of concepts around financial mechanisms and equitable distribution of funds.

For details see http://www.reddccadgiz.org/documentos/shoot.php?Descargar=REDD+\%20frequently\%20asked\%20que stions\&id=39\&f=doc_554772732.pdf\&L=0

${ }^{5}$ http://www.greenoxx.com/en/madre-de-dios-the-project.asp 
Private individuals and conservation groups have also engaged in the direct purchase of forest lands to provide environmental services. Landmatrix, an NGO devoted to tracking international land purchases, categorizes around five percent of the 70.5 million acres in their database as conservation oriented purchases. ${ }^{6}$ Wealthy individuals have famously purchased large amounts of land, including over 400,000 acres in the Amazon and several million acres in Patagonia. $^{7}$ Although these private initiatives have been met with skepticism by some governments in developing countries, who have dubbed such efforts 'eco-colonialist', this type of direct action may be a viable alternative to waiting for national governments to come to international agreements. Finally, NGO purchases of forest land are an order of magnitude greater than private individuals'. Many NGOs, such as the Nature Conservancy, Cool Earth, Woodland Trust and Wildlands Project, work on both, forming partnerships with local charities for conservation purchases and purchasing tracts of land outright. ${ }^{8}$ Beyond discussion of the ethics of such purchases (e.g. Fairhead et al., 2012), rigorous academic research on either the purpose or the impact of land purchase on environmental outcomes is extremely limited.

In summary, we have noted that the vast majority of locally and nationally financed forest-PES programs are associated with hydrological services. This is consistent with the fact that national governments need to engage with services whose benefits accrue most directly to local taxpayers. International environmental services, such as carbon sequestration and biodiversity, are most frequently financed by international organizations and NGOs. The challenges of organizing players to fund global environmental goods suggests that their provision

\footnotetext{
${ }^{6}$ Landmatrix.org

${ }^{7}$ http://www.guardian.co.uk/environment/2008/feb/13/conservation, New York Times (2005), http://www.scientificamerican.com/article.cfm?id=conflicted-conservation-efforts

${ }^{8}$ http://www.nature.org/ourinitiatives/urgentissues/global-warming-climate-change/how-we-work/noelkempff-case-study-final.pdf http://coolearth.org/, http://www.woodlandtrust.org.uk/, http://www.wildlandsprojectrevealed.org/, http://www.conservation.org/act/Pages/make_difference.aspx, http://adopt.nature.org/
} 
will be considerably farther from optimal than more localized benefits. Private initiatives by the airline industry, hotel chains engaging in offsets or private purchases of land are relatively new developments, and there is very little empirical evidence of the effectiveness and the distributional effects of these projects.

\section{The Supply of Forest Environmental Services}

In contrast to environmental service demand, which can operate on a great variety of spatial scales, the forest environmental service suppliers who participate in PES programs are mostly individuals or small communities. The literature on the supply side has broadly focused on two issues: the targeting of the individuals providing the services and the environmental effectiveness of PES programs. An important driver of effectiveness is the ability to target and calibrate payments such that the owners of land desired for inclusion in the program choose to enroll. This section begins by briefly summarizing the literature on targeting and pricing, then discusses the characteristics of the suppliers, and finally examines some existing PES programs with respect to their effectiveness to supply environmental services.

\section{Targeting and contracts - theory and reality}

The problem of studying which land to enroll into PES programs (targeting)—has much in common with targeting of conditional cash transfer programs in general in the sense that the efficacy of such programs depends upon having identified willing sellers in whom the policy can induce an actual behavior change. In this section we review work that describes optimal targeting strategies, issues of hidden information regarding opportunity costs, and ways in which they might be circumvented in the PES context. We also compare the theory on contracts with the reality of implementation in existing programs. 
According to standard economic theory, any program whose goal is to effectively provide environmental services should seek to maximize expected net benefits. In order to do so at least cost, payments should be equivalent to the opportunity cost of the supplier. This principle is best described by Babcock et al. (1997) in the context of the US Conservation Reserve Program, and is further discussed in the GE literature on climate change (i.e. Falk \& Mendelsohn, 1993) as well as the simulation-based literature that examines the costs of large-scale forest carbon sequestration policies. Here, key papers include Sohngen and Mendelsohn (2003), who originally pointed out the relatively low cost of carbon sequestration in forests, and Lubowski et al. (2006) who estimate opportunity costs using detailed observational data in the US. While these are important calculations, this literature has typically abstracted away from institutional details of implementation. The remainder of this section describes recent work that focuses on these institutional aspects to elucidate the difference between theory and reality in the field.

Targeting for afforestation and targeting for avoided deforestation present different challenges. The latter turns out to be much more difficult than choosing land for afforestation or silvopastoral practices, since policymakers need to predict where individuals would like to deforest in the near future (Alix-Garcia et al.., 2008). This 'hidden information' problem between the land owner and the government is significant and has been described in the literature both for projects in developed countries like the US (Mason \& Plantinga, 2013) and in developing country contexts (Ferraro, 2008). Ferraro (2008) nicely lays out the informational challenges of PES contracts, as well as the advantages and disadvantages of auctions: on one side, auctions clearly reduce informational rents, but in low and middle income countries there can be substantial equity tradeoffs due to auctions if payments are differentiated by land owner. 
While an auction may be the theoretically preferred tool to help to resolve the hidden information problem, there exists little experience in actually implementing these types of systems in the context of forest-PES ${ }^{9}$. Ajayi et al.. (2012) and Jack (2013) are two notable exceptions. These two papers describe an experiment in Malawi designed to elicit the exact willingness to accept a PES contract for afforestation. The experiment uses an undifferentiated payment scheme, and shows that an auction mechanism can generate significant cost-savings by identifying users with high private benefit to opportunity cost ratios for tree maintenance. This result suggests that significant private information is held by participants that is otherwise hidden to the policy designer. As the authors are unable to make comparisons with alternate targeting schemes, it is difficult to assess the scalability of such an approach. To our knowledge, no auctions have been conducted for avoided deforestation contracts. An alternative to auctions selecting program recipients based on observable risk factors - has also been shown to offer significant cost-savings in simulations (Alix-Garcia et al., 2008; Mason \& Plantinga, 2013). Although this approach has not been directly applied in actual policy settings, the more recent cohorts of Mexico's program does use a deforestation risk measure as part of targeting (Sims et al., 2013).

An additional targeting complication is that environmental services are typically connected to trees in highly non-linear ways. A fascinating review of the relationship between scientific evidence and population perceptions of the relationship between forest and environmental services can be found in Calder (2002), who shows that while the popular perception is that forests are uniformly good for increasing water flows and reducing erosion,

\footnotetext{
${ }^{9}$ In the vast majority of large scale ecosystem services programs in developing countries, payments are made per hectare of standing forest (as in Costa Rica, Mexico, Colombia, and Ecuador), or per hectare of trees planted (as in China's Sloping Land Conversion Program). See Appendix Tables I and II in Pattanayak et al. (2010) for further examples.
} 
evidence suggests that net increases in water depend very much on forest type, particularly for dry season flows, and that disturbing forests may either increase or decrease erosion, depending upon soil conditions. In the extreme, afforestation has been linked with decreased water flows in some settings (Farley et al., 2005). Clearly, biodiversity is not linearly increasing in forest area, and in fact likely depends upon the connection between contiguous areas of feasible habitat (McDonnell et al. 2002, Dreschsler et al., 2007). While the literature on the Conservation Reserve Program in the United States (CRP) has dedicated significant energy to the design of contracting mechanisms that promote agglomeration of properties (Parkhurst et al., 2002; Nelson et al., 2008; Dreschsler et al., 2010), there is currently no work that we know of investigating the design and implementation of agglomeration incentives in the forest-PES context.

When should the payment be made? Theory suggests that the optimal payment scheme is to compensate the landholder at the very end of the contracted period (Salas, et al., 2011; 2012). This is often politically unfeasible, especially in low income countries. Hence, in practice, most existing PES programs, whose contracts vary from 5 (Mexico) to 20 (Ecuador) years, tend to pay on a yearly basis, at the end of each contract year. These contracts are contingent on preserved forest or standing trees, which are relatively easy to observe. In the case of re- or afforestation, the standing tree contingency approaches the theoretical ideal, while for avoided deforestation it is more difficult due to the unobserved counterfactual baseline scenario.

In summary, the disconnect between the PES contract and the service, the difficulty of measuring the ecosystem services in question, and the fact that these are often combined with a single flat payment per hectare (perhaps stratified by some ecosystem type criterion) suggests that current PES programs are unlikely to approach cost-effectiveness. Likely because of these difficulties, we are not aware of any convincing work directly empirically measuring the value of 
biodiversity, water quality, and carbon sequestration benefits of existing forest PES, although there is an active literature simulating these effects in hypothetical programs (e.g. Sathaye et al., 2011; Carparros et al., 2010, and papers cited therein).

\section{Who receives payments?}

Because forest cover and poverty are positively correlated at a global scale, there has been a push among policymakers to promote PES as an instrument for both environmental protection and poverty alleviation (e.g. Landell-Mills \& Porras, 2002; Rios \& Pagiola, 2010; Turpie, et al.. 2008; Lipper, 2009). The question of who receives payments from existing programs begins to speak to the distributional issues which have occupied a substantial part of the discussion surrounding avoided deforestation projects and their social impacts. In this section we outline theory and evidence on program participation, leaving for section 6 the analysis of the evidence on poverty alleviation. In a conceptual paper, Wunder (2008) highlights potential situations in which the poor are left out of PES programs. Wunder shows that participation is determined by: owning enough "environmentally strategic land", trusting the purchaser, having sufficient capacity to meet program monitoring/production requirements, and having a low enough opportunity cost to make payments attractive. Clearly, some of these factors favor the poor and some the rich. Since environmental desirability can be positively or negatively correlated with the opportunity cost of participation, the question of who participates remains largely empirical.

What is the evidence on these characteristics from the empirical PES literature? A variety of cases show mixed empirical evidence on typical characteristics of PES participants and nonparticipants. Simulating the effects of a carbon sequestration program based upon land use data from Costa Rica, Pfaff et al. (2007) note that the poor tend to hold more forested land, but that 
this land is at relatively low risk of deforestation. They highlight the possibility that while carbon sequestration payments may be "pro-poor", programs seeking to limit transactions costs by enrolling large areas of land would end up in the hands of the relatively rich living in poor areas, since the landholdings of the poor tend to be smaller. Data from Costa Rica's payments for hydrological services program shows that large land holders with formal tenure to be significantly more likely to put land into the program. In comparison, households with more family farm labor are less likely to participate (Zbinden \& Lee, 2005). In Mexico, Sims et al. (2013) find that the distribution of municipal poverty across program participants tends to be generally indistinguishable from the distribution of municipal poverty across all forested areas, and that the participation of communal, generally poor, landholding households has increased over time. Participants in silvopastoral PES programs in Colombia tend to be poorer on average, but have larger farm sizes, while in Nicaragua participants have higher income per capita than non-participants, but smaller farm sizes on average (Rios \& Pagiola, 2010). A recent experiment in Uganda shows less take-up of an avoided deforestation PES scheme by credit constrained individuals (Jayachandran, 2013), a result explained by a model showing that the timing of PES payments (post-effort) makes PES unappealing to those needing immediate liquidity. In Malawi, a small tree planting experiment showed participants to be slightly poorer than the national average, although the scale and structure of the experiment limit inference on participation constraints (Ajayi et al., 2012). Finally, in China, the land enrolled in the Grain for Green program has had a high probability of contributing to soil erosion - enrolled plots have above 15 degrees in slope and are relatively low yielding (Uchida et al., 2005). Participants and nonparticipants in the program appear to have similar levels of poverty (Gauvin, et al., 2010). 


\section{Do payments actually generate environmental services?}

Does PES produce additional environmental services? Differentiating by program type, the evaluation literature shows positive results for reforestation and afforestation programs, although the number of studies is quite small. In comparison the work on avoided deforestation programs has yielded mixed outcomes. Here we begin with the avoided deforestation literature, and then move on to examples of afforestation below.

The question of environmental effectiveness of avoided deforestation programs has been recently covered very thoroughly by Pattanayak et al. (2010). We do not wish to repeat their analysis here, but rather use their conclusions as context for the few additional recent papers, as well as suggesting some additional conclusions to draw from this body of work. As Pattanayak et al. (2010) point out, there are few studies which use rigorous impact evaluation methodologies, and most of these have been conducted in Costa Rica (Pfaff et al., 2013; Robalino \& Pfaff, 2013; Arriagada et al., 2008; Sills et al., 2008) with a recent increase in work in Mexico (Alix-Garcia et al. 2012; Alix-Garcia et al., 2013). The vast majority of these studies use some form of matching (Robalino \& Pfaff 2013; Alix-Garcia, et al., 2012; Alix-Garcia et al., 2013) sometimes combined with differences in differences (Arriagada, et al., 2008; Sills et al., 2008; Alix-Garcia et al., 2013) using forest measures based upon satellite imagery.

Avoided deforestation tends to be modest when measured in terms of decreased deforestation, but larger when reported in percentage change relative to controls, since the places in which it has been measured tend to have low deforestation rates. In Mexico's payments for hydrological services program, a study of the 2004 cohort finds that the program reduces the percent area deforested by 1.19 percentage points, which amounts to an approximate decrease in deforestation of 50 percent, relative to the mean percent deforested in matched control 
properties, which is $2.4 \%$ on average. (Alix-Garcia et al., 2012). A more recent analysis of all program cohorts from 2003 to 2009 in Mexico’s Payments for Hydrological Services program finds a 40-50 percent decrease in the downward NDVI (Normalized Difference Vegetation Index) trend in the properties of PES participants relative to the control group (Alix-Garcia et al., 2013), although the downward trend in the controls is relatively small. The findings on early cohorts in Costa Rica suggest zero to small avoided deforestation effects, with positive impacts coming from afforestation rather than avoided deforestation (Pattanayak et al., 2010). A recent working paper on Costa Rica, however, finds larger and more significant impacts for land enrolled over the later period (2000-2005), as well as spatial heterogeneity in impact, with larger effects estimated in areas of lower slope and closer to cities (Pfaff et al., 2013). The authors are not able to identify an explanation for the increase in impact over time. In none of these cases has the data been sufficient to analyze what occurs when properties finish their term in a program, or disenroll early.

The existing studies on avoided deforestation programs have uniformly taken place in countries (Mexico and Costa Rica) with deforestation rates that were decreasing over the period of program. In Costa Rica, Robalino and Pfaff (2013) estimate that less than 0.4 percent of parcels enrolled in the program would have been deforested in the absence of payments. One lesson that can be extracted from this literature is that it is difficult for an avoided deforestation program to have impact in the absence of deforestation risk. Other important lessons are as follows: First, analyses from countries where deforestation risk is high but institutional strength is low will be essential for clarifying the conditions under which PES programs can be successful. Second, while deforestation is a decreasing problem in middle income countries such as Mexico and Costa Rica, degradation remains an importance source of ecosystem service loss. 
There are significant remote sensing challenges to measuring degradation, particularly in tropical countries where the phenology presents considerable challenges to techniques developed for temperate forests (Blackman, 2012). NDVI measurements do partially capture degradation, but it is still difficult to clearly separate decreases in forest quality from decreases in forest area. Improving these measures will remain an active research area.

In the afforestation literature, two recent field experiments by Jack (2013) and Jack et al. (2013) focus on measuring the impact of heterogeneous incentives to plant trees. The outcomes are simply measured as the number of trees alive at the end of the contract period. In Malawi, farmers who participated in an auction experiment to elicit their opportunity cost tend to have more live trees at the end of the contract than those receiving a fixed rate contract by lottery (Jack 2013). In preliminary work on a similar afforestation experiment in Zambia, an increase in a performance incentive results in positive impacts on the intensive margin in terms of the numbers of surviving trees, and on the extensive margin with respect to the likelihood to participate in the program (Jack et al., 2013). An alternative outcome methodology is offered by Rios and Pagiola (2010). They measure environmental benefits using an index that aggregates over a variety of environmental characteristics of enrolled land, ranging from annual agricultural crops to primary and secondary forest, and find little impact of the PES program on this index.

In summary, there has been considerable theoretical work on optimal contracts and targeting. Actual program rules, however, tend to lag the theoretical ideal. Despite this, there is evidence that afforestation and reforestation programs have had significant impacts, although there is a need for work in more varied institutional and deforestation risk environments, and there is a large hold in the literature with respect to post-program behavior by PES recipients. Recent experiments have shown significant potential for the use of auctions to increase program 
cost-effectiveness, but more information is required on the administrative costs of such programs before scaling up can be recommended without reservation. In terms of the effectiveness of avoided deforestation programs, however, the results are more mixed.

\section{Challenges to forest-PES Implementation}

In addition to the challenges discussed in the previous sections, many PES projects face two further complications, missing property rights and leakage. This section discusses the recent literature contributing to the study of these two problems.

\section{Missing property rights}

In the world of Coase, externality problems are resolved through the definition of property rights over the externality. In the world of forest-PES, lack of secure tenure over the assets that produce the externality poses one of the biggest implementation challenges, particularly in developing countries. For avoided deforestation payments to achieve additionality, payments must be targeted to areas at risk of deforestation, and both theoretical and empirical work suggests that insecure tenure can be a primary driver of deforestation. An excellent review of the relationship between tenure and forest management can be found in Robinson et al. (2011). There has been little formal theoretical work relating forest-PES to property rights. One exception to this is Barbier and Tesfaw (2013), who present a dynamic model that describes the interaction between forest-PES and customary land rights. They show that if the probability of eviction is decreased by participation in a PES program, individuals allocate more land to the project. 
So far, the literature relating property rights to program effectiveness tends to be descriptive rather than establishing causality. Costa Rica’s longstanding PES program, widely regarded as among the more successful, is predicated on well-defined property rights (Blackman \& Woodward, 2010; Arriagada et al., 2012). In Mexico, although much forested land is managed under communal tenure systems, the tenure rights of communities are mostly unchallenged, and the question of who should receive payments easily resolved (Sims et al., 2013).

There are distributional implications of tenure insecurity. Lack of formal title can serve as a significant barrier to participation of the poor (Wunder, 2008), and large resource inflows may potentially encourage capture of forest land previously considered to be of low value. A revealing study in Uganda shows that differences in the definition of land tenure could lead to adverse impacts on women's land rights in the presence of PES payments that change the value of land (Bomuhangi et al., 2011). In Brazil, efforts to formalize tenure have proceeded hand in hand with REDD+ investments, and there appears to be promise in leveraging REDD to formalize titles (Duchelle et al., 2013). In Indonesia, on the other hand, tenure conflicts and instability appear likely to undermine REDD+ effectiveness (Resosudarmo et al., 2013). A group of case studies from Brazil, Cameroon, Tanzania, Indonesia, and Vietnam reveal a variety of efforts at formalizing tenure in anticipation of REDD, but note a significant lack of coordination with national level tenurization efforts (Sunderlin et al., 2013).

\section{Spillovers}

In the PES context, there are a variety of avenues through which programs might generate unintended consequences, both negative and positive. We will discuss both types of spillovers in this section, noting first that the majority of the literature in this areas has focused on the problem of the displacement of forest exploitation by program payments known as 
leakage. The possibility for leakage, or "slippage" poses perhaps the most serious challenge to efforts to conserve or expand forests using PES type mechanisms (Plantinga \& Richards, 2008). Following the debate about slippage effects of the U.S. CRP (Wu et al., 2001; Wu, 2000; 2005; Roberts \& Bucholtz, 2005; 2006), we define two types of slippage: substitution and macro price effects. Substitution slippage effect occurs when a landowner who removes one parcel of land from production (by enrolling it in the PES program) shifts the planned production to another parcel within his landholdings. Well-functioning markets limit the possibility of substitution slippage (Roberts \& Bucholtz, 2005), but labor, credit, and land market rigidities in developing countries are more likely to lead to production displacement. There is some suggestion from the behavioral literature that negative behaviors in reaction to exclusion from PES programs could generate additional leakage (Alpizar et al., 2013), but this has not yet been observed in existing programs.

Macro price slippage occurs through general equilibrium effects if the removal of land from production increases the market price of land-intensive goods, thus changing production incentives on unenrolled land. Macro price slippage can occur on unenrolled areas within the same country, or even globally if the market is integrated internationally (such as in the global carbon market). There are a variety of price slippage models, including Robalino (2007) and Murray et al. (2004), who nicely show that lower elasticities of forest product demand generate greater leakage. Rose and Sohngen (2011), using a general equilibrium approach, simulate the global impact of different combinations of afforestation and avoided deforestation policies in order to elucidate tradeoffs and synergies between the two approaches. They find an afforestation-only scheme to be suboptimal, since price effects can actually increase 
deforestation in the short run, and conclude that it is necessary to incentivize both activities simultaneously.

Much of the evidence regarding actual price leakage effects comes from non-PES policy interventions in the US ${ }^{10}$ and Canada. Empirically, there is considerable work on the effects of limiting timber harvests, mostly from the United States. In a classic paper on price effects, Berck and Bentley (1997) find that the "taking" of 43 percent of the old growth redwood tree inventory by the US government from private industry in the 1960s and 70s resulted in an increase in the price of redwood timber by 46 percent, thus providing evidence of the price effect mechanism. Other US based studies of leakage include Wear and Murray (2004), who show how reduced public sales of timber increase private timber extraction in the US and in Canada. General equilibrium simulations of potential forest carbon leakage constitute the largest portion of the price leakage literature. This literature suggests significant cross-border leakage from forest conservation (Murray et al., 2004; 2007; Gan \& McCarl, 2007; Meyfroidt \& Lambin, 2009). ${ }^{11}$

There are almost no papers that empirically measure substitution slippage resulting from forest-PES. Two exceptions to this are Alix-Garcia et al. (2012) and Arriagada et al. (2012). The former paper illustrates one possible slippage mechanism using an agricultural household model with credit constraints. This shows evidence supporting the theory within Mexican common properties who applied to Mexico’s Payments for Hydrological Services program in

\footnotetext{
${ }^{10}$ There has been considerably empirical work on slippage related to the US CRP. While this falls outside the scope of this review, it merits mentioning that, among other effects, the CRP appears to increase production on neighboring lands (Fleming 2010), shift non-conservation uses to later periods (Jacobson 2012), and increase the value of farmland (Wu and Lin 2010).

${ }^{11}$ While details of the carbon emissions leakage literature is outside the scope of this review, we refer to Karp (2012) who makes a useful point which is also applicable to the forest PES setting: partial equilibrium models of the sort generally used to examine leakage are likely upward biased.
} 
2004. By matching between accepted and rejected applicants, Alix-Garcia et al. (2012) calculate that on average, the substitution slippage effect reduces avoided deforestation by about $4 \%$, with larger impacts among poor communities and smaller impacts among the relatively wealthy. The same paper also finds suggestive evidence of output price leakage. Indirectly addressing slippage, Arriagada et al.. (2012) conduct a whole farm analysis of Costa Rica's PES program. By including the entire area owned by an individual farmer, rather than just the area enrolled in the program, the authors are able to implicitly measure the program impact net of leakage. During the PES contract of eight years, Arriagada et al. (2012) find a net increase of $11 \%$ to $17 \%$ in total farm forest cover on participating farmers relative to matched control farms.

While leakage is a major concern in the PES literature, there is little consensus on how to combat it. Using a two-period utility maximization model to characterize a static market equilibrium framework, Barua, Uusivuori, \& Kuuluvainen (2012) show that complementing carbon payments with cash-crop taxes can be an effective method for discouraging deforestation. For substitution leakage, which involves landowners moving forest exploitation within their own properties, there is the theoretical possibility of controlling leakage with more complete contracts. There are clear practical barriers to implementing this, however, and there are not yet existing programs with contracts over all land owned by participants.

Other work on spillovers suggests the possibility of "positive leakage" from forest Conservation programs (Pfaff \& Robalino, 2012) This can occur through the following mechanisms. First, PES programs could discourage deforestation on lands adjacent to protected areas by raising expectations among landowners of future revenue from PES programs. Second, a given PES program could serve as a signal to private actors that the government will not be investing in infrastructure or industrial development in the broader region. This could thus create 
spillover effects in neighboring land parcels by reducing the incentive for land clearing. This possibility is suggested by the empirics in Robalino and Pfaff (2012), who examine the impact of neighbor decisions on deforestation behavior. However, to date, there is little empirical evidence on such positive leakage in existing PES programs

\section{Poverty alleviation and PES}

As was previously mentioned, there is considerable pressure for PES to support both environmental protection and poverty alleviation goals (e.g. Landell-Mills \& Porras, 2002; Turpie et al.., 2008; Lipper et al., 2009). Hence, there has been significant discussion in the literature of potential poverty effects of PES programs. Much of this work has been nicely reviewed in Bulte et al. (2008), Lipper et al. (2009) and in Palmer and Engel (2009). Earlier work has suggested that there are some potential situations in which the poor might benefit from PES and that there may be tradeoffs in targeting. However, robust conclusive evidence on either point is still lacking. In this section we highlight the recent conceptual and empirical work that has taken place since these reviews.

In section 3 we discussed whether or not the poor are among those receiving payments. Being a recipient of payments, however, is quite different from whether or not a PES program actually aids in moving households out of poverty. Clearly, the former is a necessary condition for the latter, but much of the poverty/PES literature focuses on participation of the poor, rather than changes in their outcomes as a result of an incentive program. Ollivier (2012) uses a general equilibrium framework to identify key tensions generated by transfers conditional on forest conservation. Under the assumption that farmers can substitute capital for land, and in the absence of labor market frictions, she shows that low transfers can increase agricultural 
productivity, and thus raise welfare, by raising the capital to land ratio. At higher transfer levels, however, the capital over land ratio becomes "too high", thus decreasing returns to agriculture. In the case where the external transfer does not fully compensate for this decrease, welfare can be reduced by the transfer.

Zilberman et al. (2008) present a useful microeconomic framework for understanding the potential impacts of both land diversion and working-land programs on PES sellers. Using a separable household model of decision making, where households vary in farm size, environmental benefits of their land holdings, and wealth, they show that in the case of landdiversion programs-such as avoided deforestation PES-the poor landholders are most likely to benefit if the main impacts of the program are through increased agricultural rents, while wage and price effects are minimal. In the same setting, landless rural poor may benefit if PES leads to higher labor demand. On the other hand landless lose if payments increase local food prices. Overall however, as in the case of the working lands programs, the increase in labor demand may lead to poverty alleviation.

On the empirical side, applied work on poverty alleviation and environmental effects exists only for China and Mexico. China's Sloped Land Conversion Program (SLCP), which pays for reforestation, does not appear to have major tradeoffs between environmental and development goals (Uchida et al., 2007; 2009; Gauvin et al., 2010). More recently, an analysis of Mexico’s PSAH program on accepted and rejected applicants reveals very interesting and significant tradeoffs between targeting on poverty alleviation versus targeting on environmental effectiveness (Alix-Garcia et al., 2013). In particular, using matching and panel data analysis, Alix-Garcia et al.. (2013) find that the environmental impact is highest where poverty is low, but poverty alleviation is highest where risk of deforestation is low. On average the wealth effects 
are small. These findings demonstrate that the claim that PES programs can both generate inexpensive carbon sequestration and alleviate poverty is not generalizable, and that the underlying correlation between poverty and deforestation risk determines the ability of a PES policy to achieve the dual objectives of poverty alleviation and environmental conservation.

Although there is scant evidence of immediate poverty alleviation resulting from PES payments, there is work suggesting potentially positive long term effects. Uchida et al. (2009) use panel data on households participating in China's national PES program (SLCP) to examine labor response to payments. The study uses a panel of data on participants and non-participants interviewed from the same village, and uses a difference in difference approach to evaluate changes in off-farm labor supply. ${ }^{12}$ The authors find that the program increased off-farm labor participation for participating households, and that this impact is larger for households that had less liquid assets prior to the program. Under the assumption that off-farm labor eventually leads to poverty alleviation, this reveals a potential indirect source of poverty alleviation through PES. The study further provides indirect evidence that SLCP does not generate sufficient local labor demand (or raise wages enough) to keep households on farm. Alix-Garcia et al. (2013) show households participating in Mexico’s PSAH are significantly more likely than non-participants to have children between the ages of 15 and 17 in school. Assuming a future payoff to the household to higher education of its children, this offers another potential avenue for longer-term effects of PES payments on recipient households.

In sum, there is little evidence that PES is harmful to poor participants, but also little case for promoting it as another anti-poverty program. The only two cases that have been studied

\footnotetext{
${ }^{12}$ Although identification in the Uchida et al.. (2009) study is imperfect (since it is not clear whether the parallel trends assumption is satisfied), the authors conduct a series of robustness checks using matching to help reduce the bias due to differential time trends.
} 
rigorously - China and Mexico - show potential long term investments enabled by forest-PES payments, but little short-term increase in assets. Studies from poorer countries with different relationships between land use and poverty may yield different results, and the increasing number of new PES programs in Africa and Asia provide an opportunity for research to help to answer these questions.

\section{The state of the literature and the future}

This paper has reviewed the recent theory and evidence on the demand, supply, and indirect effects of programs paying for forest ecosystem services. This work has taught us a considerable amount about how things should be: cost-effective contracts pay the opportunity cost to land with highest expected net benefits, payments should be made at the end of contracting periods, leakage may occur through various channels. We have also learned a bit about how things are: auctions can be used (on a small scale) to elicit hidden information regarding opportunity costs, the poor participate in PES programs in many settings, existing programs of payments for hydrological services in Latin America have been moderately effective at reducing deforestation and not particularly effective at alleviating poverty, and are probably not as cost-effective as they could be.

This review has also highlighted the need for more work to understand how such payment programs might function in weaker institutional settings, in particular, in places where land tenure is not well-established. It has also shown that the implementation of forest-PES contracts would benefit from attempting to link services more closely to contracts, in particular, the concern for agglomeration in the provision of hydrological and biodiversity services and information regarding what happens when contracts end. Also missing in the present literature 
are rigorous analyses of growing players on the global conservation scene - NGOs and individuals purchasing environmental services, sometimes on a significant scale. We have also noted the disconnect between the outcomes measured in empirical work - forest - and the actual environmental services of interest, with the caveat that measurement of the former presents challenges significant enough to undermine the effectiveness of large-scale anti-deforestation schemes. Our tour through this literature has also shown that much remains to be done to shed light on the interaction of PES payment programs with local and, eventually, the global economy, both in terms of the actual measurement of program leakage and proposals for reasonable policies to combat it.

Finally, PES programs impact people, both the owners and the "purchasers" of these services, and the information available at the moment does little to help us quantify the welfare effects of these new relationships. The spread of REDD+ projects across the globe offers significant opportunities to explore these questions in the years to come. 
Figure 1: Forest area and net forest change, 1990-2010

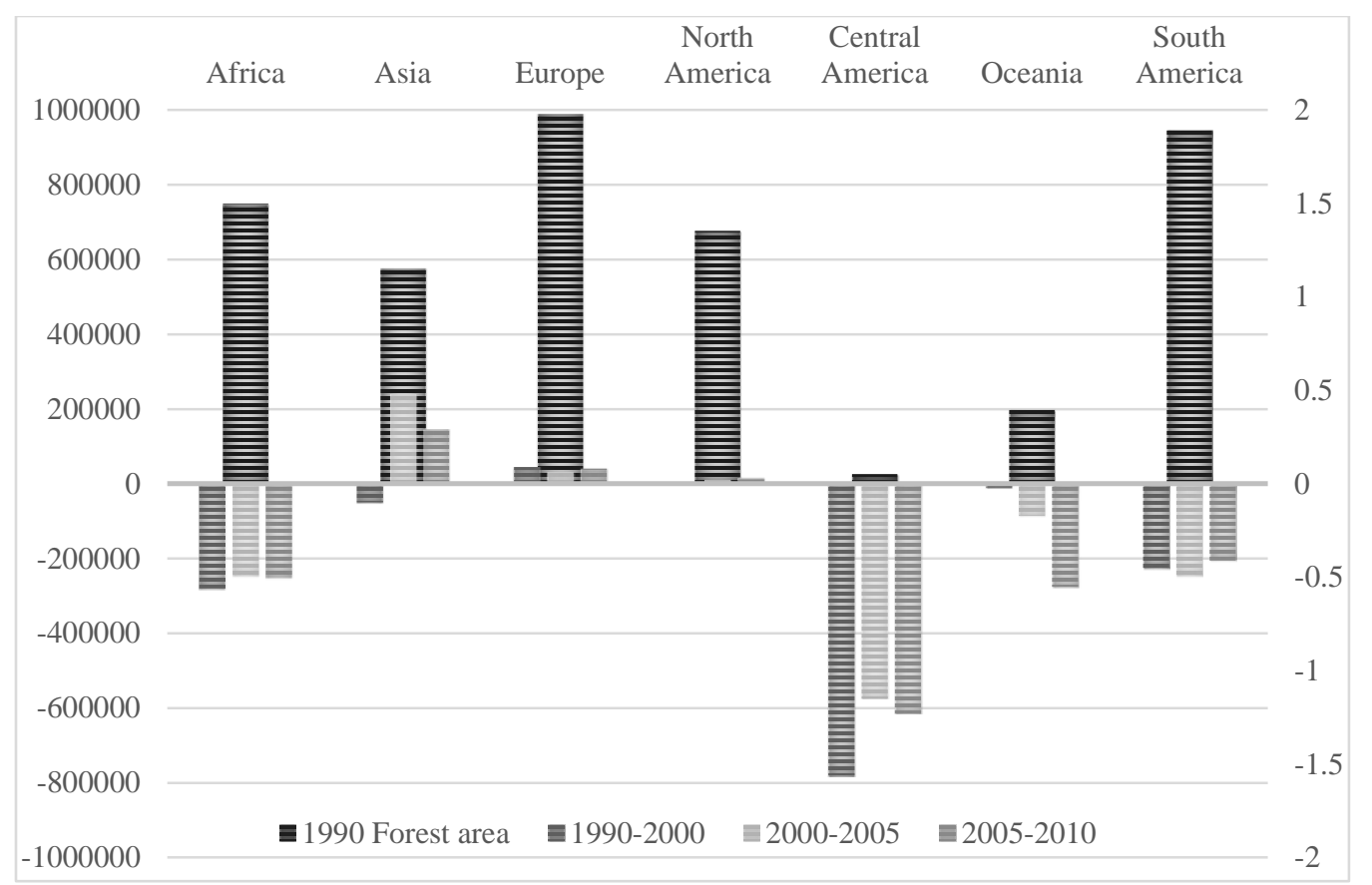

Source: FAO Forest Resources Assessment, 2010 


\section{Bibliography}

AJAYI, O. C., JACK, B. K. \& LEIMONA, B. 2012. Auction Design for the Private Provision of Public Goods in Developing Countries: Lessons from Payments for Environmental Services in Malawi and Indonesia. World Development, 40, 1213-1223.

ALIX-GARCIA, J.M., ARONSON, G., RADELOFF, V., RAMIREZ-REYES, C., SHAPIRO, E., SIMS, K.R.E, YANEZ-PAGANS, P. 2012. Evaluation of CONAFOR's Payments for Hydrological Services Program, 2003-2010. A report prepared for CONAFOR.

ALIX-GARCIA, J., DE JANVRY, A. \& SADOULET, E. 2008. The role of deforestation risk and calibrated compensation in designing payments for environmental services. Environment and Development Economics, 13, 375-394.

ALIX-GARCIA, J., SIMS, K. R. E. \& YANEZ-PAGANS, P. 2013. Only One Tree from Each Seed? Environmental effectiveness and poverty alleviation in programs of payments for ecosystem services. Working paper, University of Wisconsin, Madison, Department of Agricultural and Applied Economics.

ALIX-GARCIA, J. M., SHAPIRO, E. N. \& SIMS, K. R. E. 2012. Forest Conservation and Slippage: Evidence from Mexico's National Payments for Ecosystem Services Program. Land Economics, 88, 613-638.

ALPIZAR, F., NORDEN, A., PFAFF, A., \& ROBALINO, J. 2013. Behavioral Spillovers from Targeted Incentives: Losses from Excluded Individuals Can Counter Gains from Those Selected. Duke Energy and Environmental Economics Working Paper Series EE 13-07. 
ANGELSEN, A. \& RUDEL, T. 2013. Designing and Implementing Effective REDD plus Policies: A Forest Transition Approach. Review of Environmental Economics and Policy, 7, 91-113.

ARRIAGADA, R. A., FERRARO, P. J., SILLS, E. O., PATTANAYAK, S. K. \& CORDEROSANCHO, S. 2012. Do Payments for Environmental Services Affect Forest Cover? A Farm-Level Evaluation from Costa Rica. Land Economics.

ASNER, G. P., POWELL, G. V. N., MASCARO, J., KNAPP, D. E., CLARK, J. K., JACOBSON, J., KENNEDY-BOWDOIN, T., BALAJI, A., PAEZ-ACOSTA, G., VICTORIA, E., SECADA, L., VALQUI, M. \& HUGHES, R. F. 2010. High-resolution forest carbon stocks and emissions in the Amazon. Proceedings of the National Academy of Sciences of the United States of America, 107, 16738-16742.

BABCOCK, B., LAKSHMINARAYAN, P., WU, J. \& ZILBERMAN, D. 1997. Targeting tools for the purchase of environmental amenities. Land Economics, 73, 325-339.

BALOONI, K., \& SINGH, K. 2001. Tree plantations for restoration of degraded lands and greening of India: a case study of tree growers' cooperatives. Natural resources forum, $25,1,21-32$

BARBIER, E. B. \& TESFAW, A. T. 2013. Tenure Constraints and Carbon Forestry in Africa. American Journal of Agricultural Economics, 95, 964-975.

BARUA, S., UUSIVUORI, J. \& KUULUVAINEN, J. 2012. Impacts of carbon-based policy instruments and taxes on tropical deforestation. Ecological Economics, 73, 211-219. 
BERCK, P., \& BENTLEY, W. R. 1997. Hotelling's theory, enhancement, and the taking of the Redwood National Park. American Journal of Agricultural Economics, 79(2), 287-298.

BIERMANN, F. \& GUPTA, A. 2011. Accountability and Legitimacy in Earth System Governance: A Research Framework. Ecological Economics, 70, 1856-1864.

BLACKMAN, A. 2012. Post Evaluation of Forest Conservation Policies Using Remote Sensing Data: An Introduction and Practical Guide. Discussion Paper 12-13. Resources for the Future

BLACKMAN, A. \& WOODWARD, R.T. 2010. User financing in a national payments for environmental services program: Costa Rican hydropower. Ecological Economics, 69(8), 1626-1638.

BOMUHANGI, A., DOSS, C., \& MEINZEN-DICK, R. 2011. Who owns the land?: Perspectives from rural Ugandans and implications for land acquisitions (No. 1136). International Food Policy Research Institute (IFPRI).

BULTE, E. H., LIPPER, L., STRINGER, R. \& ZILBERMAN, D. 2008. Payments for Ecosystem Services and Poverty Reduction: Concepts, Issues, and Empirical Perspectives. Environment and Development Economics, 13, 245-254.

CALDER, I.R. 2002. Forests and hydrological services: reconciling public and science perceptions. Land Use and Water Resources Research, 2(2), 1-12.

CAPARROS, A., CERDA, E., OVANDO, P. \& CAMPOS, P. 2010. Carbon Sequestration with Reforestations and Biodiversity-scenic Values. Environmental \& Resource Economics, 45, 49-72. 
CAPARROS, A., OVANDO, P., OVIEDO, J. L. \& CAMPOS, P. 2011. Accounting for Carbon in Avoided Degradation and Reforestation Programmes in Mediterranean Forests. Environment and Development Economics, 16, 405-428.

CATTANEO, A. 2011. Robust Design of Multiscale Programs to Reduce Deforestation. Environment and Development Economics, 16, 455-478.

CHAMPAGNE, É. \& ROBERTS, J. 2009. Case Study: Brazil. Legal Frameworks for REDD: Design and Implementation at the National level. Costenbader, J.(ed), IUCN Environmental Policy and Law Paper.

COASE, R. H. 1960. THE PROBLEM OF SOCIAL COST. Journal of Law \& Economics, 3, 144.

CORBERA, E., ESTRADA, M. \& BROWN, K. 2009a. How do regulated and voluntary carbonoffset schemes compare? Journal of Integrative Environmental Sciences, 6, 25-50.

CORBERA, E., SOBERANIS, C. \& BROWN, K. 2009b. Institutional dimensions of Payments for Ecosystem Services: An analysis of Mexico's carbon forestry programme. Ecological Economics, 68, 743-761.

DRESCHLER, M., GRIMM, V., MYSIAK, J., \& WATZOLD, F. 2007). Differences and similarities between ecological and economic models for biodiversity conservation. Ecological Economics, 62(2), 232-241.

DRESCHLER, M., WATZOLD, F., JOHST, K., \& SHOGREN, J. F. 2010. An agglomeration payment for cost-effective biodiversity conservation in spatially structured 
landscapes. Resource and Energy Economics, 32(2), 261-275.

DUCHELLE, A.E., CROMBERG, M, GEBARA, M.F., GUERRA, R. MELO, T, LARSON, A., CRONKLETON, P., \& SUNDERLIN, W.D.. 2013. Linking Forest Tenure Reform, Environmental Compliance, and Incentives: Lessons from REDD+ Initiatives in the Brazilian Amazon. World Development.

ENGEL, S., PAGIOLA, S. \& WUNDER, S. 2008. Designing payments for environmental services in theory and practice: An overview of the issues. Ecological Economics, 65, 663-674.

FAIRHEAD, J., LEACH, M. \& SCOONES, I. 2012. Green Grabbing: a new appropriation of nature? The Journal of Peasant Studies, 39, 237-261.

FALK, I. \& MENDELSOHN, R. 1993. The Economics of Controlling Stock Pollutants: An Efficient Strategy for Greenhouse Gases. Journal of Environmental Economics and Management, 25, 76-88.

FARLEY, K.D., JOBBAGNY, E. G., \& JACKSON, R. B. 2005. Effects of afforestation on water yield: a global synthesis with implications for policy. Global Change Biology, 11(10), 1565-1576.

FAO 2010. Global Forest Resources Assessment 2010: Main Report, Food and Agriculture Organization of the United Nations.

FERRARO, P. J. 2008. Asymmetric Information and Contract Design for Payments for Environmental Services. Ecological Economics, 65, 810-821. 
FLEMING, D. A. 2010. Slippage Effects of the Conservation Reserve Program: New Evidence from Satellite Imagery. Selected Paper prepared for presentation at the Agricultural \& Applied Economics.

FRIEDLINGSTEIN, P., HOUGHTON, R. A., MARLAND, G., HACKLER, J., BODEN, T. A., CONWAY, T. J., CANADELL, J. G., RAUPACH, M. R., CIAIS, P. \& LE QUERE, C. 2010. Update on CO2 emissions. Nature Geoscience, 3, 811-812.

GAN, J. and MCCARL, B. 2007. Measuring transnational leakage of forest conservation. Ecological Economics 64: 423-432

GAUVIN, C., UCHIDA, E, ROZELLE, S., XU, J., \& ZHAN, J. 2010. Cost-effectiveness of payments for ecosystem services with dual goals of environment and poverty alleviation. Environmental management, 45(3), 488-501.

GROLLEAU, G., \& MCCANN, L. M. 2012. Designing watershed programs to pay farmers for water quality services: Case studies of Munich and New York City. Ecological Economics, 76, 87-94.

HOLLAND, M. B., DE KONING, F., MORALES, M., NAUGHTON-TREVES, L., ROBINSON, B. E. \& SUÁREZ, L. Complex Tenure and Deforestation: Implications for Conservation Incentives in the Ecuadorian Amazon. World Development.

IRAWAN, S., TACCONI, L. \& RING, I. 2013. Stakeholders' incentives for land-use change and REDD plus: The case of Indonesia. Ecological Economics, 87, 75-83.

JACK, B., KOUSKY, C. \& SIMS, K. 2008. Designing payments for ecosystem services: 
Lessons from previous experience with incentive-based mechanisms. Proceedings of the National Academy of Sciences of the United States of America, 105, 9465-9470.

JACK, B. K. 2013. Private Information and the Allocation of Land Use Subsidies in Malawi. American Economic Journal-Applied Economics, 5, 113-135.

JACK, B. K., OLIVA, P., WALKER, E. \& BELL, S. 2012. Encouraging the adoption of nitrogen-fixing trees: A field experiment in Zambia.

JACOBSON, S. 2010. The Effects of Conservation Reserve Program Participation on Later Land Use. Mimeo, Williams College.

JAYACHANDRAN, S. 2013. Liquidity Constraints and Deforestation: The Limitations of Payments for Ecosystem Services. American Economic Review, 103, 309-313.

KARP, L. (2012). Carbon Leakage in General and Partial Equilibrium. Mimeo, UC Berkeley Department of Agricultural and Resource Economics.

LANDELL-MILLS, N. \& PORRAS, I. T. 2002. Silver bullet or fools' gold?: a global review of markets for forest environmental services and their impact on the poor. London: International Institute for Environment and Development.

LAMBIN, E. F., GEIST, H. J. \& LEPERS, E. 2003. Dynamics of land-use and land-cover change in tropical regions. Annual Review of Environment and Resources, 28, 205-241.

LIPPER, L. (Ed.). 2009. Payment for environmental services in agricultural landscapes: Economic policies and poverty reduction in developing countries (Vol. 31). Springer. 
LUBOWSKI, R. N., PLANTINGA, A. J. \& STAVINS, R. N. 2006. Land-Use Change and Carbon Sinks: Econometric Estimation of the Carbon Sequestration Supply Function. Journal of Environmental Economics and Management, 51, 135-152.

MASON, C. F. \& PLANTINGA, A. J. 2013. The additionality problem with offsets: Optimal contracts for carbon sequestration in forests. Journal of Environmental Economics and Management, 66, 1-14.

MCDONNELL, M.D., POSSINGHAM, H.P., BALL, I.R., COUSINS, E.A.. 2002. Mathematical Methods for Spatially Cohesive Reserve Design. Environmental Modelling and Assessment. 7: 107-114.

MEYFROIDT, P., \& LAMBIN, E. F. 2009. Forest transition in Vietnam and displacement of deforestation abroad. Proceedings of the National Academy of Sciences, 106(38), 1613916144.

MURRAY, B.C., MCCARL, B.A. and LEE, H. 2004. Estimating Leakage from Forest Carbon Sequestration Programs. Land Economics, 80(1): 109-124.

MURRAY, B., SOHNGEN, B., \& ROSS, M. 2007. Economic consequences of consideration of permanence, leakage and additionality for soil carbon sequestration projects. Climate Policy 80: $127-143$.

NELSON, E., POLASKY, S., LEWIS, D. J., PLANTINGA, A. J., LONSDORF, E., WHITE, D., BAEL, D. \& LAWLER, J. J. 2008. Efficiency of incentives to jointly increase carbon sequestration and species conservation on a landscape. Proceedings of the National Academy of Sciences, 105(28), 9471-9476. 
NEWELL, R., PIZER, W. \& RAIMI, D. 2013. Carbon Markets 15 Years after Kyoto: Lessons Learned, New Challenges. Journal of Economic Perspectives, 27, 123-146.

OLLIVIER, H. 2012. Growth, deforestation and the efficiency of the REDD mechanism. Journal of Environmental Economics and Management, 64, 312-327.

PAGIOLA, S. 2008. Payments for environmental services in Costa Rica. Ecological Economics, $65,712-724$.

PAGIOLA, S., RIOS, A. \& ARCENAS, A. 2008. Can the poor participate in payments for environmental services? Lessons from the Silvopastoral Project in Nicaragua. Environment and Development Economics, 13, 299-325.

PALMER, C., \& ENGEL, S. (Eds.). (2009). Avoided deforestation: Prospects for mitigating climate change. Taylor \& Francis US.

PALMER, C. 2011. Property Rights and Liability for Deforestation under REDD+: Implications for 'Permanence' in Policy Design. Ecological Economics, 70, 571-576.

PARKHURST, G. M., SHOGREN, J. F., BASTIAN, C., KIVI, P., DONNER, J., \& SMITH, R. B. 2002. Agglomeration bonus: an incentive mechanism to reunite fragmented habitat for biodiversity conservation. Ecological economics, 41(2), 305-328.

PATTANAYAK, S., WUNDER, S. \& FERRARO, P. 2010. Show Me the Money: Do Payments Supply Environmental Services in Developing Countries? Review of Environmental Economics and Policy, 4, 254-274. 
PFAFF, A., ROBALINO, J., SANDOVAL, C., LEON, C., \& SANCHEZ-AFOFEIFA, G. 2013. "Increasing the Impacts of Payments for Ecosystem Services: location affects deforestation impact for Costa Rica's 2000-2005 PES”. Mimeo, Duke University.

PFAFF, A., AMACHER, G. \& SILLS, E. 2013. Realistic REDD: Understanding and Improving Domestic Policy Impacts on Forest Loss. Review of Environmental Economics and Policy. DOI: 10.1093/reep/res023

PFAFF, A., KERR, S., LIPPER, L., CAVATASSI, R., DAVIS, B., HENDY, J., \& SANCHEZAZOFEIFA, G. A. 2007. Will buying tropical forest carbon benefit the poor? Evidence from Costa Rica. Land Use Policy, 24(3), 600-610.

PFAFF, A., \& ROBALINO, J.A. 2012. Protecting forests, biodiversity, and the climate: predicting policy impact to improve policy choice. Oxford Review of Economic Policy 28(1): 164-179.

PLANTINGA, A. \& RICHARDS, K. 2008. International Forest Carbon Sequestration in a PostKyoto Agreement. Discussion Paper 08-11, The Harvard Project on International Climate Agreements.

RESOSUDARMO, I.A.P., ATMADJA, S., EKAPUTRI, A.D., INTARINI, D.Y., INDRIATMOKO, Y., \&ASTRI, P. 2013. Does Tenure Security Lead to REDD+ Project Effectiveness? Reflections from Five Emerging Sites in Indonesia. World Development.

RIOS, A \& PAGIOLA, S. 2010. Poor household participation in payments for environmental services in Nicaragua and Colombia. Payments for environmental services, forest conservation and climate change: Livelihoods in the Redd, 21-243. 
ROBALINO, J. 2007. Land conservation policies and income distribution: who bears the burden of our environmental efforts? Environment and Development Economics 12 (4): 521-533.

ROBALINO, J. A., \& PFAFF, A. 2012. Contagious development: Neighbor interactions in deforestation. Journal of Development Economics, 97(2), 427-436.

ROBALINO, J., \& PFAFF, A. 2013. Ecopayments and deforestation in Costa Rica: A nationwide analysis of PSA's initial years. Land Economics, 89(3), 432-448.

ROBERTS, M. J., \& BUCHOLTZ, S. 2005. Slippage in The Conservation Reserve Program or Spurious Correlation? A Comment. American Journal of Agricultural Economics 87: $244-250$

ROBERTS, M. J., \& BUCHOLTZ, S. 2006. Slippage in The Conservation Reserve Program or Spurious Correlation? A Rejoinder. American Journal of Agricultural Economics 88: $512-514$

ROBINSON, B.E., HOLLAND, M.B., \& NAUGHTON-TREVES, L. 2011. Does secure land tenure save forests? A review of the relationship between land tenure and tropical deforestation (No. 7). CCAFS Working Paper.

ROSE, S. \& SOHNGEN, B. 2011. Global forest carbon sequestration and climate policy design. Environment and Development Economics, 16, 429-454.

SALAS, P. \& ROE, B. 2012. The Role of Cooperation and Reciprocity in Structuring Carbon Sequestration Contracts in Developing Countries. American Journal of Agricultural Economics, 94, 411-418. 
SALAS, P. C., ROE, B. \& SOHNGEN, B. Addressing Additionality in REDD Contracts when Formal Enforcement is Absent. AAEA Annual Meeting, August 12-14 2012 Seattle, Washington. 1-34.

SARKAR, S., SANCHEZ-CORDERO, V., LONDONO, M. C. \& FULLER, T. 2009. Systematic conservation assessment for the Mesoamerica, Choco, and Tropical Andes biodiversity hotspots: a preliminary analysis. Biodiversity and Conservation, 18, 1793-1828.

SAMII, C., LISIECKI, M., KULKARNI, P., PALER, L., \& CHAVIS, L. 2013. Effects of Payment for Environmental Services and Decentralized Forest Management on Deforestation and Poverty in Low and Middle Income Countries: A Systematic Review. Campbell Systematic Reviews, forthcoming.

SATHAYE, J., ANDRASKO, K. \& CHAN, P. 2011. Emissions scenarios, costs, and implementation considerations of REDD-plus programs. Environment and Development Economics, 16, 361-380.

SCULLION, J., THOMAS, C. W., VOGT, K. A., PEREZ-MAQUEO, O. \& LOGSDON, M. G. 2011. Evaluating the environmental impact of payments for ecosystem services in Coatepec (Mexico) using remote sensing and on-site interviews. Environmental Conservation, 38, 426-434.

SIMS, K.R.E., ALIX-GARCIA, J.M., SHAPIRO-GARZA, E., FINE, L, RADELOFF, V.C., ARONSON, G., CASTILLO, S., RAMIREZ-REYES, C., \& YANEZ-PAGANS, P. 2013. Adaptive Management in Mexico’s Payments for Hydrological Services Program Improves Targeting for Environmental and Social Goals. Working paper, Amherst 


\section{College.}

SOHNGEN, B. \& MENDELSOHN, R. 2003. An optimal control model of forest carbon sequestration. American Journal of Agricultural Economics, 85, 448-457.

STERN, N. 2006. Review on the economics of climate change. London HM Treasury.

SUNDERLIN, W.D., LARSON, A.M., DUCHELLE, A.E., RESOSUDARMO, I.A.P., HUYNH, T.B., AWONO, A., \& DOKKEN, T. 2013. How are REDD+ proponents addressing tenure problems? Evidence from Brazil, Cameroon, Tanzania, Indonesia, and Vietnam. World Development.

THOMAS, S., DARGUSCH, P., HARRISON, S. \& HERBOHN, J. 2010. Why are there so few afforestation and reforestation Clean Development Mechanism projects? Land Use Policy, 27, 880-887.

TURPIE, J. K., MARAIS, C. \& BLIGNAUT, J. N. 2008. The Working for Water Programme: Evolution of a Payments for Ecosystem Services Mechanism That Addresses Both Poverty and Ecosystem Service Delivery in South Africa. Ecological Economics, 65, 788-798.

UCHIDA, E., ROZELLE, S. \& XU, J. 2009. Conservation Payments, Liquidity Constraints, and Off-Farm Labor: Impact of the Grain-for-Green Program on Rural Households in China. American Journal of Agricultural Economics, 91, 70-86.

UCHIDA, E., XU, J. \& ROZELLE, S. 2005. Grain for green: Cost-effectiveness and sustainability of China's conservation set-aside program. Land Economics, 81, 247-264. 
VAN HECKEN, G., BASTIAENSEN, J. \& VASQUEZ, W. 2012. The viability of local payments for watershed services: Empirical evidence from Matiguas, Nicaragua. Ecological Economics, 74, 169-176.

WU, J. 2000. Slippage Effects of the Conservation Reserve Programs American Journal of Agricultural Economics 82: 979-992.

WU, J. 2005. Slippage Effects of the Conservation Reserve Programs: Reply. American Journal of Agricultural Economics 87: 251-254.

WU, J., \& LIN, H. 2010. The effect of the conservation reserve program on land values. Land Economics, 86(1), 1-21.

WU, J., ZILBERMAN, D. and BABCOCK, B.A. 2001. Environmental and Distributional Impacts of Conservation Targeting Strategies. Journal of Environmental Economics and Management. 41: 333-350.

WUNDER, S. 2008. Payments for Environmental Services and the Poor: Concepts and Preliminary Evidence. Environment and Development Economics, 13, 279-297.

WUNDER, S. \& ALBAN, M. 2008. Decentralized payments for environmental services: The cases of Pimampiro and PROFAFOR in Ecuador. Ecological Economics, 65, 685-698.

WUNDER, S., ENGEL, S. \& PAGIOLA, S. 2008. Taking stock: A comparative analysis of payments for environmental services programs in developed and developing countries. Ecological Economics, 65, 834-852.

WUNDER, S. \& WERTZ-KANOUNNIKOFF, S. 2009. Payments for Ecosystem Services: A New Way of Conserving Biodiversity in Forests. Journal of Sustainable Forestry, 28, 
576-596.

XU, Z., XU, J., DENG, X., HUANG, J., UCHIDA, E. \& ROZELLE, S. 2006. Grain for Green versus Grain: Conflict between Food Security and Conservation Set-Aside in China. World Development, 34, 130-148.

ZBINDEN, S. \& LEE, D. R. 2005. Paying for Environmental Services: An Analysis of Participation in Costa Rica's PSA Program. World Development, 33, 255-272.

ZILBERMAN, D., LIPPER, L., \& MCCARTHY, N. 2008. When could payments for environmental services benefit the poor?. Environment and Development Economics, 13(03), 255-278. 